\title{
SURVEILLANCE OF MOSQUITOES LARVA AT SELECTED AREAS OF MYMENSINGH DISTRICT IN BANGLADESH
}

\author{
T. Farjana*, M. S. Ahmmed, T. F. Khanom¹, N. Alam and N. Begum \\ Department of Parasitology, ${ }^{1}$ Department of Environmental Science, Bangladesh Agricultural University \\ Mymensingh-2202, Bangladesh
}

\begin{abstract}
Mosquito borne diseases have a great impact on human and animal health throughout the world including Bangladesh. An entomological survey was conducted at the Bangladesh Agricultural University (BAU) campus and its surrounding areas from January to June, 2013 to identify the mosquito larvae and to investigate the different breeding site preferences of mosquitoes. Mosquito larvae were collected using dipper, ladle spoon, dropper and pipette from rice field, botanical garden, dairy farm, poultry farm, drains, lakes, ponds, staff quarters, residential halls and cattle sheds. A total of 1397 mosquito larvae were collected from the places. Ten species of mosquitoes under three genera were identified. The recorded genera were Anopheles (An.), Culex (Cx.) and Aedes (Ae.). The collected species were An. bengalensis, An. vagus, Cx. fuscocephala, Cx. quinquefasciatus, Cx. tritaeniorhynchus, Cx. gelidus, Cx. vishnui, Cx. whitmorei, Cx. sitiens and Ae. albopictus. Among the collected larvae, Culex was found most prevalent (64.3\%), followed by Anopheles (26.7\%) and Aedes were the least prevalent (9.0\%). The results of this study provide evidence that drains were the most common aquatic habitat of Anopheles and Culex larvae in Boyra, Kewatkhali and Balashpur. In BAU campus, agronomy fields were found having the highest percentage (35.2\%) of mosquito larvae than the other places of the campus. This study suggests that although drains and rice fields are the richest habitats, since Anopheles and Culex can breed in all available breeding habitats. This larval survey will help us to conduct future mosquito control activities and provide us useful information to schedule larvicide's application to control the mosquito borne diseases in the study areas as well as throughout the country.
\end{abstract}

Key Words: Mosquito, breeding site, larval surveillance, Mymensingh

\section{INTRODUCTION}

Mosquitoes are regarded as well-known vector of diseases like dengue, Japanese encephalitis, yellow fever, malaria, and filariasis (Bang, 1985; Halstead, 1966). They are also important nuisance pests. Mosquito born diseases are the major public health problem in Bangladesh (Ahmed et al., 1986; Aziz et al., 1967; Hossain et al. 2000; Khan et al., 1981; Khan and Ahmed, 1986; Rosenberg and Maheswary, 1982; Wolfe and Aslamkhan, 1971).

Mosquito genera differ in their habitat requirements and lifecycle timeframe. There are four main stages in the lifecycle of mosquitoes egg, larva, pupa and adult. The developmental stages (egg to adult) may take as little as 5 days to as long as 1 month depending on species as well as geographic location and temperature. The eggs are laid in water either singly (Anopheles spp. \& Aedes spp.) or in egg raft of 200-300 eggs (Culex spp.). Eggs hatch within one week and then go through four instars which feed on small organisms like algae or decaying organic material (Clements, 1992).

Mosquitoes prefer to breed in all sorts of stagnant water. Running streams and creeks with any water movement or ponds with predators such as fish, frogs, or dragonflies are not good breeding sites for mosquitoes. Mosquitoes need only a few tablespoons of water to breed. Mosquito larvae can be found in various habitats. Some larvae are active in transient waters such as floodwater, ditches and woodland pools. The Anopheles, Culex, Culiseta, Coquillettidia and Uranotaenia species breed in permanent bodies of water and can survive in polluted water as well as freshwater, acid water and brackish water swamps. Other mosquito larvae may be present in container water sources such as puddles upon leaves and stagnant water within small pools (Bashar et al., 2005).

The dengue vectors breed both in artificial and natural containers. Aedes aegypti is an urban species, whereas An. albopictus prefers to breed in the rural conditions. The filariasis vector, Cx. quinquefasciatus is the most versatile species breeding nearly everywhere with a wide biting activity pattern. Mansonia breeds with aquatic plants, while $C x$. tritaeniorhynchus prefers to breed in rice fields (Khan et al., 1981).

*Corresponding e-mail address: thahsinfarjana@gmail.com 


\section{T. Farjana and others}

Anopheles stephensi, a vector of malaria in some urban areas in south Asia, often breeds in wells, ponds, cisterns and containers used for the storage of drinking water (Saleeza et al., 2011).

Mosquito surveillance is a prerequisite to an effective, efficient, and environmentally sound mosquito control program. Surveillance is used to define the nature and extent of the mosquito problem and to gauge daily mosquito control operations. It provides a basis for evaluating the effectiveness of control operations, the data needed to comply with state rules and regulations regarding the justification for treatments, and a basis for evaluating the potential for transmission of mosquito-borne diseases. Mosquito surveillance is most effective when combined with an ongoing program for monitoring meteorological, astronomical, and environmental factors that may influence mosquito population change. For example, rainfall and ground water levels, temperature, relative humidity, wind direction and velocity, tidal changes, lunar cycles, storm water and wastewater management, and land use patterns are all factors that may influence mosquito population levels and adult mosquito flight behavior and dispersal (Senior-White, 1926).

Surveys are essential for the planning, operation and evaluation of an effective mosquito-control program, whether for the prevention of mosquito-borne diseases or to reduce mosquito populations to levels permitting normal activities without undue discomfort. Initial surveys identify the species of mosquitoes present and provide general information on locations, densities and disease potential. With this knowledge it may be possible to determine life cycles and feeding preferences; predict larval habitats, adult resting places and flight ranges; and perhaps even make preliminary recommendations for control programs. A basic inspection program usually addresses adult and larval population density and species composition, rainfall and tide monitoring, and breeding site locations. This information not only provides justification for source reduction and insecticide applications, but it also serves as an ongoing indicator of the effectiveness of these activities and continually adds to the database of knowledge concerning mosquitoes in the area. Such inspections do not determine the absolute population of mosquitoes, but they can show fluctuations in relative mosquito abundance and diversity over time in the various habitats visited (Malaria epidemiological surveillance system, M\&PDC 1997).

Considering the necessity of larval surveillance in mosquito control program, the present study was conducted to record the status of mosquito larvae as well as their breeding sites in Bangladesh Agricultural University (BAU) campus and its surrounding area in Mymensingh from January to June, 2013.

\section{MATERIALS AND METHODS \\ Study areas}

The present study was conducted to record the status of vectors and others mosquito species as well as their breeding sites and breeding behavior, larval habitat, morphology and their abundance in Bangladesh Agricultural University (BAU) campus (agronomy rice field, poultry farm, dairy farm, boys halls, botanical garden and from residential staff quarter) and its surrounding areas (Kewatkhali, Boyra and Balashpur) in Mymensingh. This research has been done from January to June 2013. The campus is made up of a series of academic, administrative and residential buildings and experimental farms, gardens and other related facilities. The surrounding areas of BAU campus (Kewatkhali, Boyra, Balashpur) are densely populated and have good breeding grounds around them. Ponds, lakes, drains, ditches are also available in these areas. Most of the people of these areas use mosquito net, few people use aerosol and mosquito coil to prevent mosquito bite. Mosquito larviciding is not practiced in these locations. Inadequate management system, poor water supply and drainage systems of these areas are responsible for mosquito breeding.

\section{Identification of mosquito breeding places}

Identification of mosquito breeding sites is accomplished through regular examination of potential breeding locations and selection of water samples. Stagnant, still water is essential for mosquito breeding. Rice fields, poultry farm, dairy farm, residential halls, residential staff quarters, lakes, ponds, drains where stagnant water with wastes are available, mosquito larvae can be found there. Since mosquitoes breed in almost any kind of water body it is important to check all water bodies during a larval survey. The habitat of mosquitoes are as that is described by the Guidelines to searching for mosquito breeding habitats (stagnant water) and conducting larval survey (2005). 
In the present study the mosquito larvae were collected from the open habitats and close habitats. There were so many open habitats for mosquito breeding such as, drains and ditches, ponds, water storage or other manmade containers, puddles and tire tracks, rice or paddy field, agricultural pits construction pits, foundations and man-made holes, stream and river beds. Closed habitats were the soakage pits, manholes and septic tanks.

\section{Collection, transportation and counting of larvae}

The mosquito larvae were collected by a standard dipping method with a dipper. Water sampling is accomplished with an old fashioned water dipper attached to a handle. Larvae were collected by ladle spoon, pipette, dipper and dropper from different spot. While dipping, care was taken so that shadow was cast away from the habitat as larvae are very sensitive and will dive to the bottom once shadow is cast on the water. The dipper was gently lowered in an angle of $45^{\circ}$ just below the surface. Proper care was taken not to disturb the water too much as this will make larvae dive downwards. When lifting the water, care was taken not to spill the water containing the larvae. Dipper was hold steadily until larvae were raised to the water surface in the dipper. At least 10 dips were taken per habitat in different locations where mosquito larvae can be expected. For further studies in the laboratory, collected larvae were transferred by means of a bottle or vials. The vials were labeled (date, name of sampling habitat) and then transported to the laboratory. During shipment care was taken so that the mosquito larva do not gets shrinked or squeezed. Larval numbers was counted and calculated on a numerical basis as per dip. Environmental data and climatic variables during the period of mosquito activity (from January to June, 2013) were considered.

\section{Identification of larval mosquito species}

All mosquitoes are classified in the order Diptera and in the family Culicidae, which has more than 3,500 recognized species in the world. Adult mosquitoes are small, long-legged flies that have two wings. But mosquito larvae morphologically differ greatly to that of an adult mosquito. Some common features of a mosquito larva, which separates them from other true flies- all mosquito larvae are dorsoventrally flattened and the body divided into three parts; head, thorax and abdomen. Head bears several structures like antenna, eye, mental plate, mouth brush, and upper and lower head hair, pre antennal and antennal hair. Larval abdomen is segmented; usually bears 8 to 10 segment. Lateral hair may or may not be present and presence of siphon tube (except Anopheles sp.). Air plugs are present in siphon tube which controls air. Comb and anal gills are present in anal segment. Mosquito larvae were identified in the laboratory of Entomology, Department of Parasitology, BAU. The larvae were identified by simple method and by preparation of permanent slides. Mosquito larvae were identified using the keys of Barraud (1933), Bram (1967), Puri (1938) and Knight and Stone (1977).

\section{Statistical analysis}

Students " $t$ " test was done and the significance level of various mosquito species was calculated using statistical package SPSS-11.5.

\section{RESULTS AND DISCUSSION \\ Overall prevalence of mosquito larvae}

The present study was conducted to know the prevalence of mosquito larva and their breeding preferences in BAU campus and its surrounding areas. Mosquito larvae were collected from BAU campus (rice field, poultry farm, dairy farm, drains of boys hall, botanical garden, residential staff quarter), Kewatkhali (railway colony, drain, open manhole), Boyra (cowshed, drain), Balashpur (pond, rice field, roadside lake, drain)in several days and times by using dipper, ladle spoon, pipette and dropper. Larval mosquito collection using a hand dipper is the preferred type because dipper samples are comparatively easier to collect mosquito larvae (Service, 1993).

The results obtained in this study showed diversity in mosquito species present at the study area. From sampled locations, a total of 1397 mosquito larvae were collected and identified during the study period from January to June, 2013. Altogether ten species of mosquito larvae under three genera were identified. The identified three genera were Anopheles (An.), Culex (Cx.) and Aedes (Ae.). The species were An. bengalensis (Plate a), An. vagus (Plate b), Cx quinquifasciatus (Plate c), Cx. fuscocephala (Plate d), Cx. tritaniorhynchus (Plate e), Cx. gelidus 


\section{T. Farjana and others}

(Plate f), Cx. vishnui (Plate- g), Cx. sitiens (Plate h), Cx. whitmorei (Plate i) and Aedes albopictus (Plate j, k, 1). The abundance of the 3 mosquito genera varied with the highest abundance of Culex

spp. followed by Anopheles and Aedes. Among the collected larvae, 898 (64.3\%) larvae were found to be Culex, $373(26.7 \%)$ were Anopheles and 126 (9.0\%) were Aedes (Table 1).

Table 1. Overall prevalence of mosquito larvae

\begin{tabular}{|c|c|c|c|c|c|}
\hline \multirow[t]{2}{*}{ Species } & \multirow[t]{2}{*}{ No. of larvae } & \multirow{2}{*}{$\begin{array}{l}\text { Prevalence } \\
(\%)\end{array}$} & \multicolumn{2}{|c|}{ Larvae in $1000 \mathrm{ml}$ water } & \multirow[t]{2}{*}{$\mathrm{Pd}$} \\
\hline & & & Range & Mean \pm SE & \\
\hline Cx. tritaeniorhynchus & 279 & 19.9 & $47-127$ & $64.63 \pm 8.394$ & 1.36 \\
\hline Cx. quinquefasciatus & 305 & 21.8 & $32-159$ & $79.51 \pm 10.698$ & 1.53 \\
\hline Cx. fuscocephala & 146 & 10.5 & $23-69$ & $41.43 \pm 7.003$ & 0.71 \\
\hline Cx. gelidus & 77 & 5.5 & $15-42$ & $33.00 \pm 5.06$ & 0.36 \\
\hline$C x$. whitmorei & 26 & 1.9 & $5-14$ & $13.75 \pm 2.869$ & 0.13 \\
\hline Cx. vishnui & 48 & 3.4 & $10-27$ & $19.20 \pm 2.80$ & 0.24 \\
\hline Cx. sitiens & 17 & 1.3 & $5-12$ & $6.0 \pm 0.750$ & 0.09 \\
\hline Sub total & 898 & 64.3 & $5-159$ & $2.80 \pm 79.51$ & \\
\hline An. bengalensis & 236 & 16.9 & $17-132$ & $58.29 \pm 6.837$ & 1.18 \\
\hline An. vagus & 137 & 9.8 & $39-94$ & $47.00 \pm 2.846$ & 0.66 \\
\hline Sub total & 373 & 26.7 & $17-132$ & $2.846 \pm 58.29$ & \\
\hline Ae. albopictus & 126 & 9.1 & $9-89$ & $42.00 \pm 24.132$ & 0.63 \\
\hline Total & 1397 & & & & \\
\hline
\end{tabular}

$* \mathrm{Pd}=$ per dip, Total no of dip used to collect mosquito larva $=200$

Culex was the most abundant species and was recorded at all the habitats investigated. The occurrence of Culex species recorded in this study is similar to the findings of Anosike et al. (2007) and Hopkins (1952). Culex species has been noted to be very common in polluted waters and sites which have foul smell (Anosike et al., 2007), and the larvae collected in this study were done mostly from polluted drain, ditches, cowshed, poultry farm etc. having foul smell, and waste products, gutters etc. Among the 10 species identified from different breeding sites of 4 different areas like BAU campus, Boyra, Kewatkhali and Balashpur, as a whole, $C x$ quinquifasciatus was the most abundant (21.8\%) species followed by Cx. tritaniorhynchus (19.9\%), An. bengalensis $(16.9 \%)$ and $C x$. fuscocephala (10.5\%). The similar findings were reported by Aslamkhan and Wolf (1972) in Dhaka city and Ameen and Moizuddin (1973) in Dinajpur district. Culex quinquefasciatus is widely distributed in urban and rural areas of Bangladesh as the presence of many irrigation ditches and rice fields provides suitable breeding site for this mosquito (Hossain et al., 1996).

\section{Prevalence of mosquito larvae in BAU campus}

In BAU campus, larval sample were collected from agronomy rice field, poultry farm, dairy farm, boys halls, botanical garden and from residential staff quarter. A total of 526 mosquito larvae were collected from various location of BAU campus, in which Culex (61.4\%) was the most prevalent followed by Anopheles $(21.7 \%)$ and Aedes (16.9\%) (Table 2).

Nine different mosquito species were identified, namely An. bengalensis (11.6\%), An. vagus (9.8\%), Cx. quinquefasciatus (19.2\%), Cx. tritaeniorhynchus (17.5\%), Cx. fuscocephala (10.8\%), Cx. gelidus (6.3\%), Cx. vishnui $(5.1 \%)$, Cx. whitmorei (2.5\%), Ae. albopictus (16.9\%) were found from different locations of BAU campus (Table 2). Among the 9 identified mosquito species in BAU campus the highest prevalence was found for Cx. quinquifasciatus (19.2\%) followed by Cx. tritaniorhynchus (17.5\%) and Aedes albopictus (16.9\%). The 
lowest prevalence was found in the species of $C x$. whitmorei $(2.5 \%)$, where as $C x$. sitiens were not found in BAU campus during the study period (Table 2). Culex species usually breed profusely in polluted gutters, blocked drains and other water retention habitats with organic matter unlike Aedes and Anopheles mosquitoes which prefer clean ground pools and man-made containers, respectively (Khan and Ahmed, 1986). The study area has many polluted drains and runoffs which could have provided conducive environment for the prolific breeding of Culex species.

Table 2. Regional prevalence of mosquito larva

\begin{tabular}{|c|c|c|c|c|c|c|c|c|}
\hline \multirow[b]{2}{*}{ Name of Species } & \multicolumn{2}{|c|}{ BAU } & \multicolumn{2}{|c|}{ Kewatkhali } & \multicolumn{2}{|c|}{ Boyra } & \multicolumn{2}{|c|}{ Balashpur } \\
\hline & $\begin{array}{l}\text { No of } \\
\text { larvae } \\
\text { collected }\end{array}$ & $\%$ & $\begin{array}{l}\text { No of } \\
\text { larvae } \\
\text { collected }\end{array}$ & $\%$ & $\begin{array}{l}\text { No of } \\
\text { larvae } \\
\text { collected }\end{array}$ & $\%$ & $\begin{array}{l}\text { No of } \\
\text { larvae } \\
\text { collected }\end{array}$ & $\%$ \\
\hline Cx. tritaeniorhynchus & 92 & 17.5 & 48 & 16.1 & 61 & 23.3 & 78 & 25.2 \\
\hline Cx. quinquefasciatus & 101 & 19.2 & 59 & 19.7 & 54 & 20.6 & 91 & 29.4 \\
\hline Cx. fuscocephala & 57 & 10.8 & 31 & 10.6 & 23 & 8.9 & 35 & 11.3 \\
\hline Cx. gelidus & 33 & 6.3 & 15 & 5.0 & 00 & 0.0 & 29 & 9.4 \\
\hline CX. whitmorei & 13 & 2.5 & 00 & 0.0 & 5 & 1.9 & 8 & 2.9 \\
\hline Cx. vishnui & 27 & 5.1 & 10 & 3.3 & 00 & 0.0 & 11 & 3.6 \\
\hline$C x$. sitiens & 00 & 0.0 & 5 & 1.7 & 00 & 0.0 & 12 & 3.9 \\
\hline Sub total & 323 & 61.4 & 168 & 56.2 & 143 & 54.6 & 264 & 85.2 \\
\hline An. bengalensis & 63 & 12.0 & 56 & 18.7 & 71 & 17.2 & 46 & 14.8 \\
\hline An. vagus & 51 & 9.8 & 47 & 15.3 & 39 & 14.9 & 00 & 0.0 \\
\hline Sub total & 114 & 21.7 & 103 & 34.5 & 110 & 42.0 & 46 & 14.8 \\
\hline Ae. albopictus & 89 & 16.9 & 28 & 9.4 & 9 & 3.5 & 00 & 0.0 \\
\hline Total & 526 & & 299 & & 262 & & 310 & \\
\hline
\end{tabular}

Mosquito larvae were collected from various breeding places of BAU campus on the basis of available breeding ground. The highest number of mosquito larvae (185) were collected from agronomy field, followed by botanical garden (91), dairy farm (83), residential staff quarter (71), poultry farm (56) and boys hall (37) (Table 3). In BAU campus, agronomy fields were found having the highest percentage $(35.2 \%)$ of mosquito larvae than the other places of the campus (Fig. 1). It might be due to presence of suitable breeding places with irrigation water in the agronomy fields during the study period. Culex quinquifasciatus was the leading species in agronomy rice fields, poultry farm, dairy farms and boys hall, whereas $C x$. tritaeniorhynchus was most prevalent species in residential staff quarters (Table 3). Although population of both Cx. quinquefasciatus and Cx. tritaeniorhynchus was varied among places in BAU campus, they usually showed no distinct preference for a particular habitat as breeding sites (Service, 1993). The percentage of Ae. albopictus (61.5\%) was the highest in botanical garden (Table 3). During the study period Aedes mosquitoes were found to be highest in botanical garden among the study areas. Dengue fever was unknown in Bangladesh until an outbreak occurred in 1964, known as "Dacca fever" (Aziz et al., 1967). Several entomological studies showed the presence of Aedes mosquitoes in Dhaka City. But there was no record of presence of Aedes spp. in Mymensingh city. Though this study, as far our knowledge, was the first survey of mosquito breeding places in BAU campus. In addition, search of dengue patient in Mymensingh Medical College hospital revealed no patients during the study period. Container breeding mosquito has been favored by poor urban infrastructure (like old part of Dhaka city) such as, an unreliable or absent water supply, which forces residents to store water, or no refuse collection, which results in accumulations of water bearing discards suitable as larval habitats (Gubler, 2002). In Mymensingh, the polluted water breeding places present as such clear water breeder mosquitoes were more in study areas. Mainly Aedes mosquito laid eggs in flexible plastic pipes for downspout drainage, buckets, watering cans, drinking glasses, plastic cups, bottle caps, or any trash that can hold water, cans and containers, old tires recycle, bird baths, ornamental ponds, puddles and wet, soggy areas. House with large premises had both artificial and natural containers where Aedes mosquitoes breed (Khan et al., 1981). There are many natural breeding containers (tree hole, leaf axils, old 


\section{T. Farjana and others}

watering cane, and flower tob) might be the reason of presence of Aedes mosquito in botanical garden of BAU campus.

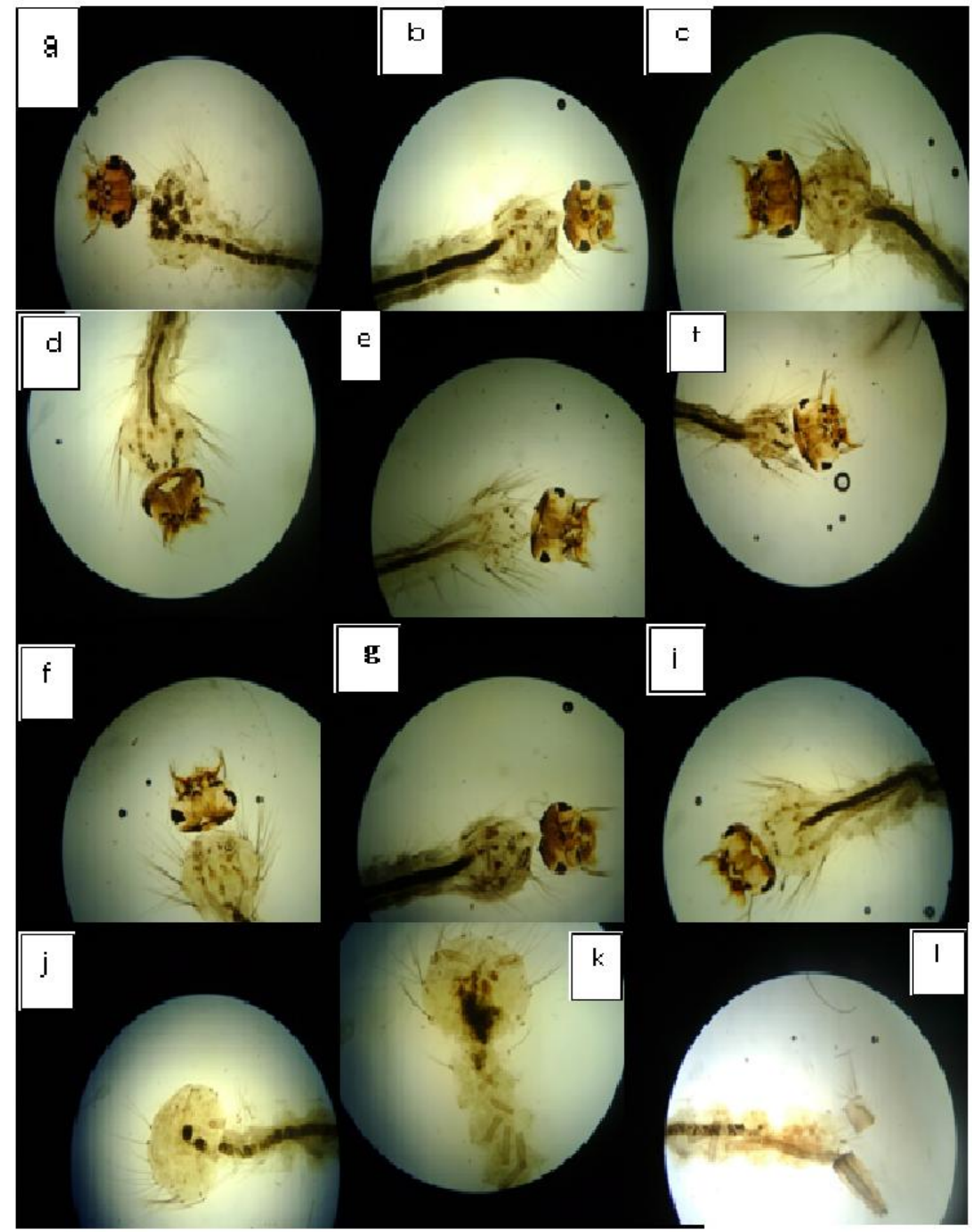

Plates: Larvae of Anopheles bengalensis (a), An. vagus (b), Culex quinquifasciatus (c), Cx. fuscocephala (d), Cx. tritaniorhynchus (e), Cx. gelidus (f), Cx. vishnui (g), Cx. sitiens (h), Cx. whitmorei (i) and Aedes albopictus (j, k, l). 


\section{Prevalence of mosquito larvae in Kewatkhali}

In Kewatkhali, a total of 299 mosquito larvae were collected from railway colony staff quarters and drains in which Culex were 166 (55.5\%), Anopheles were 103 (34.5\%) and Aedes larvae were 28 (9.4\%) (Table 2). Nine mosquito species were identified in Kewatkhali, the Culex species were Cx. quinquifasciatus (19.7\%), Cx. tritaniorhynchus (16.1\%), Cx. fuscocephala (10.6\%), Cx. gelidus (5.0\%), Cx. vishnui (3.3\%), and Cx. sitiens $(1.7 \%)$. Culex whitmorei was absent in Kewatkhali. Here also Culex was the leading mosquito genus as like as BAU campus. The Anopheles species were An. bengalensis (18.7\%), and An. vagus (15.3\%). Aedes albopictus $(9.4 \%)$ were found (Table 2). A total of 110 mosquito larvae were collected from railway colony staff quarters in Kewatkhali, in which Culex were 57 (51.8\%), Anopheles were 40 (36.4\%) and Aedes larvae were $13(11.8 \%)$ (Table 3). Among 189 mosquito larvae collected from drains of Kewatkhali, Culex were 111 (58.7\%), Anopheles were 63 (33.3\%) and Aedes larvae were 15 (7.9\%) (Table 3). The percentage of An. bengalensis (20.9\%) was the highest in railway colony quarters, whereas $C x$. quinquifasciatus $(19.6 \%)$ was the highest in drains of Kewatkhali (Table 3). Drains (63.2\%) were the most suitable breeding place than in railway colonies in Kewatkhali.

\section{Prevalence of mosquito larvae in Boyra}

A total of 262 mosquito larvae were collected from different places of Boyra in which Culex were 143 (54.6\%), Anopheles were 110 (42.0\%) and Aedes larvae were 9 (3.4\%) (Table 2). Eight species were identified from Boyra, in which Anopheles species were An. bengalensis (17.2\%), An. vagus (15.0\%), Culex species were Cx. quinquifasciatus (20.6\%), Cx. tritaniorhynchus (23.3\%), Cx. fuscocephala (8.9\%), Cx. whitmorei (1.9\%). Culex vishnui and $C x$. sitiens were not found from Boyra. Aedes albopictus (3.4\%) was also found from Boyra (Table 2). A total of 65 mosquito larvae were collected from cattle shed in Boyra of which $C x$. quinquefasciatus was found most prevalent (61.5\%) species. The presence of high number of $C x$. quinquefasciatus in cowshed may be due to the presence of cow dung, shed surrounded by polluted water and comparatively darkness of cowshed. Among 197 mosquito larvae collected from drains of Boyra, Cx. tritaeniorhynchus (25.38\%) found the leading species (Table 3). Though Cx. quinquefasciatus and $C x$. tritaeniorhynchus have the similar spatial distribution, since the former species grows relatively darker places (Senior-White, 1926). As like as Kewatkhali, drains of Boyra were the most favorite breeding place for mosquitoes than in cowshed. In this study, Aedes albopictus was found in drains of Boyra which showed the conformity with the findings of Jannat et al., 2005 in Jahangirnagar University campus.

\section{Prevalence of mosquito larvae in Balashpur}

A total of 310 mosquito larvae were collected from ponds, rice fields, roadside lake and drains of Balashpur in which Culex was the most prevalent (85.2\%) than Anopheles (14.8\%) (Table 2). Eight species of 2 genera were identified from Balashpur, Aedes was not found in Balashpur. The Culex species were Cx. quinquifasciatus (29.4\%), Cx. tritaniorhynchus (25.2\%), Cx. fuscocephala (11.3\%), Cx. gelidus (9.4\%), Cx. vishnui (3.6\%), Cx. whitmorei $(2.9 \%)$ and Cx. sitiens (3.9\%) (Table 2). Only An. bengalensis (14.8\%) was found from Balashpur, while An. vagus was absent. A total of 43 mosquito larvae were collected from pond in Balashpur of which 38 (88.37\%) were Culex and 5 (11.63\%) were Anopheles (Table 3). Mosquito larvae were collected from 4 different breeding places of Balashpur in which the highest number of mosquito larvae (161) were collected from dranis, followed by rice fields (71), ponds (43) and roadside lakes (35) (Table 3). In Balashpur, drains were found having the highest percentage (51.9\%) of mosquito larvae than the other places (Fig. 2). Culex quinquifasciatus was the leading species in drains, rice fields, roadside lakes and ponds, whereas $C x$. tritaeniorhynchus was $2^{\text {nd }}$ most prevalent species (Table 3). Culex quinquefasciatus is widely distributed over all the localities, similar findings have been reported in Dhaka city (Ahmed, 1996).

The results of this study provide evidence that drains are the most common aquatic habitat and the most common habitat containing Anopheles and Culex larvae in Boyra, Kewatkhali and Balashpur. Mosquito larvae showed a wider distribution in drain segments with various characteristics, particularly waste accumulation (Castro et al., 2010). Culex quinquefasciatus was found in all kinds of habitats and abundantly in stagnant drains suitable for its regeneration. However, breeding habitats such as drains and rice field were the richest habitats for the mosquitoes in the study areas. Blocked drains are important breeding place for not only $C x$. quinquefasciatus mosquitoes (Ameen et al., 1999), also for other Culex and Anopheles species (Ameen and Moizuddin, 1973; Ahmed, 1996). 


\section{T. Farjana and others}

Table 3. Distribution of mosquito larvae of different species in BAU, Kewatkhali, Boyra and Balashpur.

\begin{tabular}{|c|c|c|c|c|c|c|c|c|c|c|c|c|c|c|}
\hline \multirow[t]{2}{*}{ Species } & \multicolumn{6}{|l|}{ BAU } & \multicolumn{2}{|c|}{ Kewatkhali } & \multicolumn{2}{|l|}{ Boyra } & \multicolumn{4}{|c|}{ Balashpur } \\
\hline & $\begin{array}{l}\text { AGF } \\
(\%)\end{array}$ & $\begin{array}{l}\mathrm{PF} \\
(\%)\end{array}$ & $\begin{array}{l}\mathrm{DF} \\
(\%)\end{array}$ & $\begin{array}{l}\mathrm{BH} \\
(\%)\end{array}$ & $\begin{array}{l}\text { RSQ } \\
(\%)\end{array}$ & $\begin{array}{l}\mathrm{BG} \\
(\%)\end{array}$ & $\begin{array}{l}\text { RWC } \\
(\%)\end{array}$ & $\begin{array}{l}\text { DRN } \\
(\%)\end{array}$ & $\begin{array}{l}\text { CS } \\
(\%)\end{array}$ & $\begin{array}{l}\text { DRN } \\
(\%)\end{array}$ & $\mathrm{P}(\%)$ & $\begin{array}{l}\mathrm{RF} \\
(\%)\end{array}$ & $\begin{array}{l}\text { RSL } \\
(\%)\end{array}$ & $\begin{array}{l}\text { DRN } \\
(\%)\end{array}$ \\
\hline $\begin{array}{l}\text { Cx.quinqu } \\
\text { efaciatus }\end{array}$ & $\begin{array}{l}38 \\
(20.5) \\
\end{array}$ & $\begin{array}{l}21 \\
(35.6) \\
\end{array}$ & $\begin{array}{l}18 \\
(21.7) \\
\end{array}$ & $\begin{array}{l}16 \\
(22.5) \\
\end{array}$ & $\begin{array}{l}6 \\
(16.2) \\
\end{array}$ & $\begin{array}{l}11 \\
(12.1) \\
\end{array}$ & $\begin{array}{l}22 \\
(20.0) \\
\end{array}$ & $\begin{array}{l}37 \\
(19.6)\end{array}$ & $\begin{array}{l}20 \\
(61.5)\end{array}$ & $\begin{array}{l}34 \\
(17.3)\end{array}$ & $\begin{array}{l}15 \\
(34.9)\end{array}$ & $\begin{array}{l}23 \\
(22.5)\end{array}$ & $\begin{array}{l}22 \\
(65.7)\end{array}$ & $\begin{array}{l}37 \\
(22.9)\end{array}$ \\
\hline $\begin{array}{l}\text { Cx.tritaeni } \\
\text { orhynchus }\end{array}$ & $\begin{array}{l}19 \\
(10.2)\end{array}$ & $\begin{array}{l}16 \\
(27.1)\end{array}$ & $\begin{array}{l}9 \\
(10.8)\end{array}$ & $\begin{array}{l}11 \\
(15.5)\end{array}$ & $\begin{array}{l}7 \\
(18.9)\end{array}$ & $\begin{array}{l}21 \\
(23.2)\end{array}$ & $\begin{array}{l}18 \\
(16.4)\end{array}$ & $\begin{array}{l}30 \\
(15.9)\end{array}$ & $\begin{array}{l}11 \\
(16.9)\end{array}$ & $\begin{array}{l}50 \\
(25.4)\end{array}$ & $\begin{array}{l}11 \\
(25.6)\end{array}$ & $\begin{array}{l}16 \\
(14.1)\end{array}$ & $\begin{array}{l}10 \\
(28.6)\end{array}$ & $\begin{array}{l}35 \\
(21.7)\end{array}$ \\
\hline $\begin{array}{l}\text { Cx.fuscoce } \\
\text { phala }\end{array}$ & $\begin{array}{l}29 \\
(15.7)\end{array}$ & $\begin{array}{l}8 \\
(13.6)\end{array}$ & $6(7.2)$ & $\begin{array}{l}8 \\
(11.3)\end{array}$ & $\begin{array}{l}6 \\
(16.2)\end{array}$ & 0 & $\begin{array}{l}10 \\
(9.1)\end{array}$ & $\begin{array}{l}21 \\
(11.1)\end{array}$ & $\begin{array}{l}8 \\
(12.3)\end{array}$ & $\begin{array}{l}15 \\
(7.6)\end{array}$ & $\begin{array}{l}7 \\
(16.3)\end{array}$ & $\begin{array}{l}11 \\
(15.5)\end{array}$ & 0 & $\begin{array}{l}17 \\
(10.6)\end{array}$ \\
\hline Cx. gelidus & $\begin{array}{l}14 \\
(7.7)\end{array}$ & 0 & $8(9.6)$ & $\begin{array}{l}9 \\
(12.7)\end{array}$ & 0 & $2(2.3)$ & $5(4.6)$ & $\begin{array}{l}10 \\
(5.3)\end{array}$ & 0 & 0 & $3(6.9)$ & $7(9.9)$ & $2(5.7)$ & $\begin{array}{l}17 \\
(10.6)\end{array}$ \\
\hline Cx. vishnui & $\begin{array}{l}11 \\
(5.9)\end{array}$ & 0 & $4(4.8)$ & $7(9.9)$ & $\begin{array}{l}5 \\
(13.5)\end{array}$ & 0 & $3(2.7)$ & $7(3.7)$ & 0 & 0 & 0 & $2(2.8)$ & 0 & $\begin{array}{l}9 \\
(5.6)\end{array}$ \\
\hline Cx. sitiens & 0 & 0 & 0 & 0 & 0 & 0 & 0 & $5(2.7)$ & 0 & 0 & 0 & 0 & 0 & $\begin{array}{l}12 \\
(7.5)\end{array}$ \\
\hline $\begin{array}{l}\text { Cx. } \\
\text { whitmorei }\end{array}$ & $\begin{array}{l}8 \\
(4.3)\end{array}$ & 0 & $5(6.0)$ & 0 & 0 & 0 & 0 & 0 & 0 & $\begin{array}{l}5 \\
(2.5)\end{array}$ & $2(4.7)$ & $6(8.5)$ & 0 & 0 \\
\hline $\begin{array}{l}\text { Ae. } \\
\text { albopictus }\end{array}$ & $\begin{array}{l}12 \\
(6.6) \\
\end{array}$ & $\begin{array}{l}8 \\
(13.6) \\
\end{array}$ & 0 & $6(8.5)$ & $\begin{array}{l}7 \\
(18.9) \\
\end{array}$ & $\begin{array}{l}56 \\
(61.5) \\
\end{array}$ & $\begin{array}{l}13 \\
(11.8)\end{array}$ & $\begin{array}{l}15 \\
(7.9)\end{array}$ & 0 & $\begin{array}{l}9 \\
(4.7) \\
\end{array}$ & 0 & 0 & 0 & 0 \\
\hline $\begin{array}{l}\text { An. } \\
\text { Bengalensi } \\
s\end{array}$ & $\begin{array}{l}29 \\
(15.7)\end{array}$ & $\begin{array}{l}6 \\
(10.2)\end{array}$ & $\begin{array}{l}14 \\
(16.9)\end{array}$ & $7(9.9)$ & $\begin{array}{l}6 \\
(16.2)\end{array}$ & $1(1.0)$ & $\begin{array}{l}23 \\
(20.9)\end{array}$ & $\begin{array}{l}33 \\
(17.5)\end{array}$ & $\begin{array}{l}26 \\
(40.0)\end{array}$ & $\begin{array}{l}45 \\
(22.8)\end{array}$ & $\begin{array}{l}5 \\
(11.6)\end{array}$ & $6(8 . .5)$ & 0 & $\begin{array}{l}35 \\
(21.7)\end{array}$ \\
\hline An. vagus & $\begin{array}{l}25 \\
(13.5)\end{array}$ & 0 & $\begin{array}{l}19 \\
(22.9)\end{array}$ & $7(9.9)$ & 0 & 0 & $\begin{array}{l}17 \\
(15.5)\end{array}$ & $\begin{array}{l}30 \\
(15.9)\end{array}$ & 0 & $\begin{array}{l}39 \\
(19.9)\end{array}$ & 0 & 0 & 0 & 0 \\
\hline Sub total & 185 & 59 & 83 & 71 & 37 & 91 & 110 & 189 & 65 & 197 & 43 & 71 & 35 & 161 \\
\hline Grand total & 1397 & & & & & & & & & & & & & \\
\hline
\end{tabular}

${ }^{* *}$ AGF (Agronomy Field), PF (Poultry Farm), DF (Dairy Farm), RSQ (Residential Staff Quarter ), BH (Boys Hall), BG (Botanical Garden), RWC (Railway Colony), DRN (Drain), CS (Cowshed), P (Pond), RF (Rice Field), RSL (Road Side Lake)

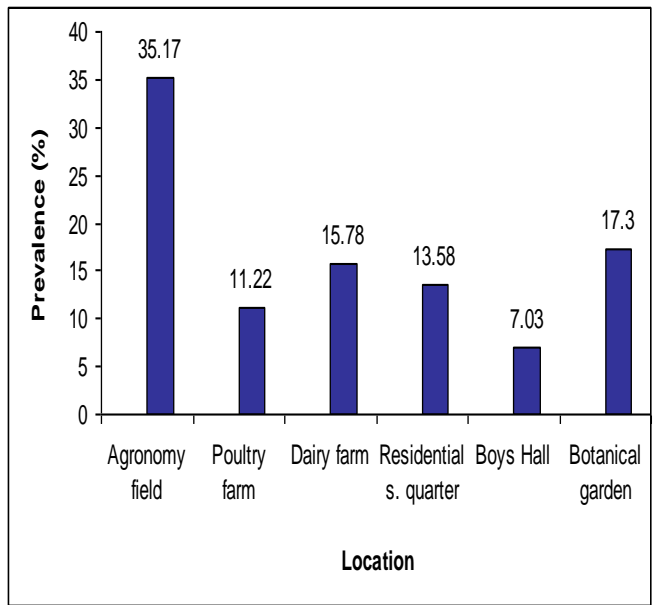

Fig 1. Prevalence of mosquito species in different locations of BAU campus

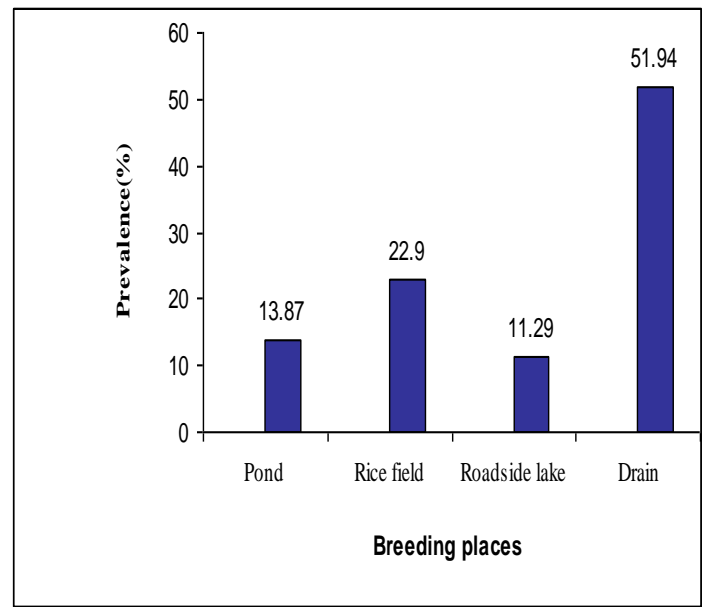

Fig 2. Prevalence of mosquito species in different breeding places at Balashpur 
Among the Culex species e.g. Cx. quinquefasciatus, $C x$. tritaeniorhynchus, Cx. fuscocephala were dominant and found almost in every location whereas the $C x$. vishnui, $C x$. gelidus, Cx. sitiens and Cx. whitmorei were found low in abundance during the study period. Among the 2 species of Anopheles, An. bengalensis was found to be dominant species and An. vagus was low in number in the study area. The similar abundance of these species also observed in different studies (Castro et al., 2010, Bashar et al., 2005).

Interestingly, there was a very strong positive association between the presence of Anopheles and the presence of Culex. Similar findings have been reported from habitats in rural areas in East and West Africa (Fillinger et al., 2004) indicating that there is no clear separation between 'typical' Anopheles and Culex larval habitats.

From the present data on mosquito breeding places for six month of study time, it can be suggested that although different breeding grounds showed as richest habitat for different species, since Anopheles and Culex can breed in all available breeding habitats. In all studied areas Culex was the most prevalent genus, while Anopheles was also present at the same breeding places. There was a positive association between the presence of Anopheles and the presence of Culex which means that there is no clear separation between Anopheles and Culex breeding places, while Aedes mosquitoes breeds in the human associated places. Proper planning is needed for larval control operations in selected areas for mosquito control. This larval survey will help us to select the sites of larvicide's application and to conduct future mosquito control activities. Environmental variables that could determine the occurrence and relative abundance of these mosquitoes were not determined, therefore, further research must be continued to know the ecology of the mosquito species.

\section{REFERENCES}

1. Ahmed TU (1996). Mosquito problem in Bangladesh with special emphasis on urban mosquito situation and its control. Key note presentation at the conference of the Entomological Society of Bangladesh, pp. 10- 25.

2. Ahmed TU, Maheswary NP and Khan NI (1986). Filariasis in Mirpur area of Dhaka City, Bangladesh. Medical Research Council Bulletin 12: 83-94.

3. Ameen M, Hossain MI and Chowdhury MA (1999). Integrated mosquito management in Dhaka city: Promising non-chemical components. Proceedings of the $3^{\text {rd }}$ International Conference on Urban Pests, Prague, Czech Republic, pp. 678.

4. Ameen M and Moizuddin M (1973). Bionomics of the common mosquitoes of Dacca. Journal of Natural History 7 : $1-21$.

5. Anosike JCBE, Nwoke AN, Okere EE, Oku JE, Asor IO, Emmy-Egbe and Adimike DA (2007). Epidemiology of tree-hole breeding mosquitoes in the tropical rainforest of Imo state, South East Nigeria. Annals of Agricultural Environment and Medicine 14: 31-38.

6. Aslamkhan M and Wolfe MS (1972). Bancroftian filariasis in two villages in Dinajpur District, East Pakistan. The American Society for Tropical Medicine and Hygiene 21: 30-37.

7. Aziz MA, Gorham JR and Greg MB (1967). "Dacca fever", an outbreak of Dengue. Pakistan Journal of Medical Research 6: 83-92.

8. Bang YH (1985). Integrated management of urban mosquito vectors of diseases. Journal of Communicable Disease 17: $1-10$.

9. Barraud PJ (1933). The fauna of British India, including Ceylon and Burma, Diptera, Family-Culicidae, TribesMegarhinini and Culicini. Taylor and Francis, London, 463.

10. Bashar K, Samsuzzaman M, Ullah MS and Iqbal MJH (2005). Surveillance of Dengue vectors mosquito in some rural areas of Bangladesh. Pakistan Journal of Biological Sciences 8: 1119-1122.

11. Bram RM (1967). Contribution to the mosquito fauna to South-East Asia, II. The genus Culex in Thailand (Diptera; Culicidae). Contribution to American Entomological Institute 2: 1-296.

12. Castro MC, Kanamori S, Kannady K, Mkude S, Killeen GF and Fillinger U (2010). The importance of drains for the larval development of lymphatic filariasis and malaria vectors Dar Es Salaam, United Republic of Tanzania. Plos One Tropical Disease 4: 693-699.

13. Clements AN (1992). The Biology of Mosquitoes, Vol.1. Development, Nutrition and Reproduction. Chapman \& Hall, New York, NY, pp: 26-45.

14. Fillinger U, Sonye G, Killeen GF, Knols BG and Becker N (2004). The practical importance of permanent and semi-permanent habitats for controlling aquatic stages of Anopheles gambae sensu latu mosquitoes; operational observation from a rural town in western Kenya. Tropical Medicine and International Health 9: 1274-1289.

15. Gubler DJ (2002). Epidemic dengue/ dengue hemorrhagic fever as a public health, social and economic problem in 21st century. Trands Microbiology10: 100-103. 


\section{T. Farjana and others}

16. Halstead SB (1966). Mosquito-borne haemorrhagic fevers of South and South-East Asia. Bulletin of World Health Organization 35: 3-15.

17. Hopkins GHE (1952). Mosquitoes of Ethiopian region, I. Larval Bionomics of Mosquitoes and Taxonomy of Culicine Larvae. $1^{\text {st }}$ Edition, British Museum (Natural History), London, 335.

18. Hossain MI, Wagatsuma Y, Chowdhury MA, Ahmed TU, Uddin MA, Sohel SMN and Kittayapong P (2000). Analysis of some socio demographic factors related to DF/DHF outbreak in Dhaka city. Dengue Bulletin 24: 34-41.

19. Hossain MI, Ameen M, and Chowdhury MA (1996). Mosquito breeding grounds in the city of Dhaka. Journal of Life Science 8: 41-47.

20. Jannat KNE, Baqui MA and Ahmed TU (2005). The status of dengue vector mosquito Aedes spp. in Dhaka. Bangladesh Journal of Life Science 17: 15-23.

21. Khan AM, Khan AQ, Dobrzynasky L, Joshi GP and Hung M (1981). A Japanese encephalitis focus in Bangladesh. American Journal of Tropical Medicine and Hygiene 48: 41-44.

22. Puri IM (1931). Larvae of anopheline mosquitoes, with full description of those of the Indian species. Department of Parasitology, John Hopkins University pp. 21: 227.

23. Rosenberg R and Maheswary NP (1982). Forest Malaria in Bangaldesh. American Journal of Tropical Medicine and Hygiene 31: 175-182.

24. Saleeza SNR, Norma-Rashid Y and Sofian-Azirun (2011). Mosquito larval breeding habitat in urban and sub-urban areas, Peninsular Malaysia. World Academy of Science, Engineering and Technology 58: 569.

25. Senior-White R (1926). Physical factors in mosquito ecology. Bulletin of Entomological Research 16: 187-248.

26. Service MW (1993). Mosquitoes (Culicidea) in Medical insects and Arachnids. Chapman and Hall, London, pp. 238.

27. Wolfe MS and Aslamkhan M (1971). Filariasis in East Pakistan. Transaction of Royal Society Tropical Medicine and Hygiene 65: 63-69. 